\title{
The Causal Analysis: A Great Way to Tell the Financial Story
}

\author{
Phil Greenwood (University of Wisconsin - Madison)
}

KEYWORDS: Entrepreneurship, Finance, Accounting, Financial reporting.

Entrepreneurs are often expected to present the current financial status of their enterprise to investors, bankers and employees. In board meetings, the entrepreneur needs to explain their current plan but, more importantly, to identify and explain why actual results differ from the original plan and to revise the annual plan going forward. Often, the entrepreneur and the financial team will present a detailed set of financial statements with way too much detail. This causes the discussion to focus on minutiae and not on the strategy and the big picture.

One "tried and tested" method used in business to present financial information is through the use of a 'causal analysis' summary. A causal analysis presents the causes of changes in financial results at a summary level from plans or prior periods. It provides enough detail to highlight the issues but presents the result in a way that can keep focus on the strategic issues. This article shows how to develop and present a causal analysis, using an example from a larger company, with the objective of highlighting the benefits of presenting financial results in a way to not lose focus on the strategic issues at hand.

\section{Identifying the drivers of change}

A "causal analysis" is a process of presenting variance analysis by identifying, at a summary level, the key items driving change in business operations. In many circumstances, companies present the standard columns of financial numbers comparing year-to-year, plan vs. actual, or plan vs. plan. In a related column and/or on separate slides will be the specific variance (i.e., one period change from another) in terms of dollars or \%. Finally, verbal or written highlights are presented to explain the material changes in categories.

A "causal" takes a different approach. It attempts to quantify (within a tabular format) the major drivers of variance attempting to separate out unusual or extraordinary events within operations and their related financial impact. By doing so, management can easily

isolate extraneous events and show a clearer picture of ongoing operations. The following example will illustrate the concept.

Babcock Laboratories (fictional) is a major pharmaceutical company that has experienced significant growth in the past 10 years, from just over $\$ 1$ billion in 2001 sales to $\$ 5.3$ billion in 2017 . Corresponding with the growth in sales has been strong increase in operating earnings, from $\$ 150$ million in 2001 to $\$ 1.2$ billion in 2017, respectively. However, in 2018, Babcock experienced a downturn in both sales and operating earnings resulting from several external factors. Table 1 provides the standard breakdown of changes in Profit/Loss between 2018 and 2017. \{Note: Column C shows Favorable/(Unfavorable) variances. An increase (decrease) in Sales and Profits is Favorable (Unfavorable) while an increase (decrease) to expenses is Unfavorable (Favorable)\}.

Table 1: Babcock Operating Results - 2018 and 2017 (In \$Billions)

(A)

(B)

(B) $-(\mathrm{A})=(\mathrm{C}) /$

(C)

\$ Change $\%$ Change

$\begin{array}{lllll}2018 & 2017 & \begin{array}{l}\text { Fav/(Unfa vs. } \\ \text { v) }\end{array} & \text { Var }\end{array}$

Sales $\quad \$ 5.0 \quad \$ 5.3 \quad(0.3) \quad(5.7 \%)$

Cost of $1.8 \quad 1.6 \quad(0.2)$

Goods

Sold

Gross $\quad 3.2 \quad 3.7$

$(0.5)$

.


Profit

Marketing 1.0

0.9

$(0.1)$

(11.1\%)

Expenses

\section{Research 0.5 \\ and Devel \\ opment \\ Expenses}

0.4

$(0.1)$

(25.0\%)

\section{General 1.1 \\ and Admin \\ istrative \\ Expenses}

$\begin{array}{llll}\text { Total } 2.6 & 2.5 & (0.1) & (4.0 \%) \\ \text { Operating } \\ \text { Expenses }\end{array}$

$\begin{array}{llll}\text { Earnings } & \$ 0.6 \quad \$ 1.2 \quad(\$ 0.6) \quad(50.0 \%)\end{array}$

Initial analysis of the table suggests a decline of almost $6 \%$ in sales and $1 / 3$ in operating earnings. Management, in anticipation of questions from the investor community, suggested the deteriorating condition was primarily due to:

- Babcock's major antibiotic came off patent in June 2018 causing a sales decline of $\$ 200$ million. Babcock didn't lose any share but as a result had to match generic competition by reducing prices by $50 \%$. Babcock management believed that the sales decline from price reductions "fell through" to the bottom line, causing a corresponding $\$ 200$ million decrease in operating earnings (i.e., no impact on Cost of Goods or Operating Expenses).

- Continued (illegal?) importation of product from Canada was estimated to have a negative impact on sales to the tune of $\$ 400$ million in 2018. Volumes appeared steady as the drugs imported were still Babcock, but management estimated that the loss in pricing power was the total cause in the sales decline.

Prior to adapting the causal analysis format, Babcock management added separate tables and narration to account for the aforementioned factors. Instead, the causal will be able to identify each factor, the related impact on sales and earnings, and provide an estimate of ongoing operations without the impact of the extraneous items.

\section{Preparing the Causal}

Column 1 in Table 2 below follows the format of a summarized Income Statement with each row representing one of the major profit/loss categories. Columns 2 and 7 represent changes in revenues and expenses for both 2001 and 2002, respectively. The columns in the middle of the table $(3-7)$, attempt to explain the major causes for the variance between the two years. The causal example for Babcock Labs summarizes management's representation of the two major events discussed earlier.

Table 2: Babcock Laboratories - Causal Analysis for Variance between 2017 and 2018 (in \$Billions)

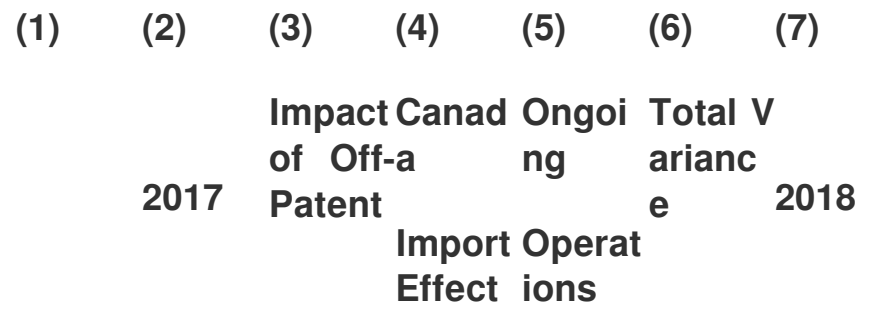

$\begin{array}{llllll}\text { Revenu } \$ 5.3 \quad(0.2) & (0.4) & 0.3 & (0.3) & \$ 5.0\end{array}$

es

$\begin{array}{llllll}\text { Cost of1.6 -- } & -- & (0.2) & (0.2) & 1.8\end{array}$

Goods

Sold

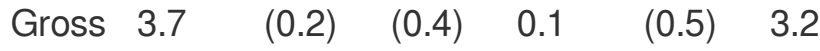

Profit

$\begin{array}{llllll}\text { Marketi } 0.9 \quad-- & -- & (0.1) & (0.1) & 1.0\end{array}$

ng Exp

enses

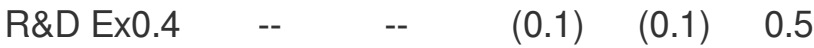


penses

S, G\&1.2 --
A Expe
nses

$\begin{array}{llllll}\text { Total O2.5 } & -- & -- & (0.1) & (0.1) & 2.6 \\ \text { peratin } & & & & & \\ \text { g Expe } & & & & & \\ \text { nses } & & & & \end{array}$

$\begin{array}{llllll}\text { Operati } \$ 1.2 & (0.2) & (0.4) & (0.0) & (\$ 0.6) & \$ 0.6 \\ \text { ng Earn } & & & & & \\ \text { ings } & & & & \end{array}$

After taking out the impact on operations of the offpatent drug and the impact of drugs imported from Canada, the results presented in column 5, "Ongoing Operations" suggest a less "bad" scenario as revenues increased combined with a variety of favorable and unfavorable variances. Column 6 is the summary of the variances (columns $\mathbf{3 + 4 + 5}$ ) that correspond with the total variance in Table 1 for years 2017 vs. 2018.

\section{Benefits of a Causal Analysis}

Using a causal analysis provides management with a tool to present a summary financial analysis that isolates the impact of "special" items from that of ongoing operations. It simplifies information for external users such as investors and analysts. More importantly, the causal isolates the ongoing operations that are more directly influenced by managers and employees.

In the simplified example above, only two issues were separated. In reality, it's not unusual to separate five or more items to highlight their affect on the financial results. Some of them might include:

- Major events such as earthquakes or strikes in other countries.

- New product launches where management and investors may want to see the impact of new sales, any cannibalization of other products, incremental marketing or other expenses.

- Exchange rate fluctuations if international sales exist.

- Operating results from "high" inflation countries.

- The change in results caused by major price increases.
- Major restructuring savings and expenses.

Finally, it should be noted that causal analysis can be used in a variety of situations: Actual vs. Actual; Plan vs. Actual; Plan vs. Revised Plan; Plan vs. Plan in later years; Department or Company level Actual/Budget; etc.. In its simplest form, a causal analysis can be used in any situation where two numbers are being compared to one another and one is attempting to explain the difference in the numbers.

While the benefits are apparent, be aware that the causal analysis possesses the same limitations of any financial reporting tool. First, if the numbers are not accurate, neither will the causal. Second, judgment is used by management to select what factors should be isolated. Those events that are separated from ongoing operations may in fact be a part of operations and should not be kept separate. Upper management and external users must continue to ask penetrating questions to identify such possibilities. Finally, management must still understand the numbers when presenting the information. They should be able to easily see the impact under differing scenarios where items are separated from (or included in) ongoing operations.

\section{Conclusion}

In summary, the causal analysis is a simple and effective tool used to identify in greater detail the changes in major profit/loss categories. Causal analysis reports can serve as a way to communicate the changes without a significant amount of narrative attached to the standard variance presentation. Causals are great for presenting to investors in a pitch deck, to existing investors or board members during periodic meetings where the financial results are discussed, and to employees of any enterprise outlining the performance of their own company without getting bogged down into meaningless details. 